\title{
Levels of serum osteocalcin and some electrolytes in foal during the first six months of life (Brief Report)
}

\author{
Osteocalcinspiegel und ausgewählte Elektrolytwerte im Serum \\ von Fohlen während der ersten sechs Lebensmonate (Brief Report)
}

\begin{abstract}
ALESSANDRO ZUMBO' ${ }^{1}$, STEFANIA CASELLA², AMBRA DI ROSA' ${ }^{1}$, SALVATORE SCIANÒ'1, FRANCESCO FAZIO ${ }^{2}$ and GIUSEPPE PICCIONE ${ }^{2}$
\end{abstract}

${ }^{1}$ Dipartimento di Morfologia, Biochimica, Fisiologia e Produzioni Animali, Università di Messina, Italy, ${ }^{2}$ Dipartimento di Scienze Sperimentali e Biotecnologie Applicate, Università di Messina, Italy

\section{Background}

Bone is a dynamic tissue characterized by continuous bone formation and bone resorption. The transformation of the primordial part of the long bones (the cartilaginous matrix during the embryonal period) into the definitive bone (lamellar bone tissue) is completed after puberty. Osteocalcin, also called the vitamin k-dependent protein of bone and synthesized predominantly by osteoblasts and in lower way by odontoblasts, is incorporated into the extracellular matrix of bone (LEPAGE et al. 2001) and it may function as a useful indicator of the equine bone growth rate which decreases considerably with age. In particular, osteocalcin or bone Gla-protein is a small abundant non-collagenous calcium binding protein, indigenous to the organic matrix of bone dentin and possibly other mineralized tissue, which circulates in the blood (LEPAGE et al. 1991). It is accepted as a marker of osteoblast activity (RISTELI and RISTELI 1993) and plays a not yet defined role in the regulation of bone turnover (BOSKEY et al. 1998).

\section{Procedures}

Ten San Fratellano foals ( 6 males and 4 females) were used in the experiment. Blood samples were taken from the jugular vein by vacutainer tubes (Terumo Corporation, Japan). Recordings and collections were done every 30 days for six months at the same hours (09.00) on all animals. Blood samples were centrifuged at $3000 \mathrm{~g} \times 10 \mathrm{~min}$ and obtained sera were stored at $-20^{\circ} \mathrm{C}$ until analyses. Serum concentration of calcium, sodium, chloride, potassium, phosphorus, iron, copper and zinc was analyzed with commercially available kits by means of a UV spectrophotometer (Slim SEAC, Firenze, Italy). Serum concentration of osteocalcin was quantified by the use of an equine-specific RIA test (Diasorin S.P.A., Saluggia, Italy). The validity of this kit for horse was reported by INOUE et al. (2008). The sensitivity of the RIA was $0.2 \mathrm{ng} / \mathrm{ml}$. One-way repeated measures analysis of variance (ANOVA) was used to determine significant differences. $P<0.05$ was considered statistically significant. The Bonferroni's test was applied for post hoc comparison. Data were analyzed using software STATISTICA 7.0. Furthermore, the following morphological measurements were performed every month on each foal: Withers height, Shoulder length, Chest measures, Rump height, Neck length, Shin length, 
Pasterns length, Breast width, Shoulder width and Width of jaws. Measurements were performed on each subject in an upright, quadruped position, on a horizontal platform, in accordance with the measuring method recommended for each somatic parameter (CATALANO 1993), using Lydtin's stick, flexible meters and calliper. Also, a Pearson's analysis of correlation between osteocalcin levels and the morphological traits indicated above was performed.

\section{Results}

As showed in Table 1, ANOVA showed a statistical significant effect of age only on osteocalcin $\left(F_{(5,40)}=2.65 ; P<0.03\right)$ from the first month vs the sixth month of life. So, we can confirm that the major physiological determinant of osteocalcin in foals is the age. The results emphasized a growth rate more rapid in younger than in the older animals. osteocalcin confirms this pattern of a higher bone growth rate in younger animals and a significant correlation between osteocalcin and age of the animals $\left(r^{2}=0.96\right)$. This negative correlation between the age of the animal and serum osteocalcin is showed by mean levels of serum osteocalcin higher at birth than in next months. The analysis of correlation between osteocalcin levels and somatic traits also showed some interesting results $(P<0.01)$. These data are considered indicative of a significant slowdown in the rate of bone formation in older foals.

Table 1

Mean values $( \pm S D)$ of calcium, sodium, chloride, potassium, phosphorus, iron, copper, zinc and osteocalcin during the first six months of life in ten foals

Mittelwerte $( \pm S D)$ von Kalzium, Natrium, Chlorid, Kalium, Phosphor, Eisen, Kupfer, Zink und Osteocalcin bei zehn Fohlen während der ersten sechs Lebensmonate

\begin{tabular}{lcccccc}
\hline Parameters & 1st month & 2nd month & 3rd month & 4th month & 5th month & 6th month \\
\hline $\mathrm{Ca}, \mathrm{mmol} / \mathrm{l}$ & $3.66 \pm 0.54$ & $3.43 \pm 0.49$ & $3.68 \pm 0.69$ & $3.51 \pm 0.70$ & $3.64 \pm 0.58$ & $3.70 \pm 0.63$ \\
$\mathrm{Na}, \mathrm{mmol} / \mathrm{l}$ & $154.72 \pm 22.43$ & $165.81 \pm 27.75$ & $167.79 \pm 30.73$ & $148.61 \pm 27.45$ & $160.56 \pm 27.67$ & $48.93 \pm 30.19$ \\
$\mathrm{Cl}, \mathrm{mmol} / \mathrm{l}$ & $154.01 \pm 27.96$ & $142.48 \pm 28.89$ & $148.12 \pm 28.99$ & $154.30 \pm 29.02$ & $143.22 \pm 28.20$ & $145.31 \pm 26.36$ \\
$\mathrm{~K}, \mathrm{mmol} / \mathrm{l}$ & $3.21 \pm 0.76$ & $2.89 \pm 0.45$ & $2.76 \pm 0.72$ & $2.81 \pm 0.96$ & $3.29 \pm 0.61$ & $3.23 \pm 0.83$ \\
$\mathrm{P}, \mathrm{mmol} / \mathrm{l}$ & $1.93 \pm 0.51$ & $1.78 \pm 0.36$ & $1.88 \pm 0.68$ & $2.07 \pm 0.68$ & $1.80 \pm 0.38$ & $2.05 \pm 0.42$ \\
$\mathrm{Fe}, \mu \mathrm{mol} / \mathrm{l}$ & $29.46 \pm 6.83$ & $28.26 \pm 5.24$ & $20.35 \pm 6.99$ & $24.93 \pm 5.67$ & $24.01 \pm 5.72$ & $18.30 \pm 5.94$ \\
$\mathrm{Cu}, \mu \mathrm{mol} / \mathrm{l}$ & $28.57 \pm 7.35$ & $32.30 \pm 7.90$ & $28.57 \pm 7.60$ & $28.81 \pm 6.86$ & $31.70 \pm 6.18$ & $29.96 \pm 7.26$ \\
$\mathrm{Zn}, \mu \mathrm{mol} / \mathrm{l}$ & $16.60 \pm 3.80$ & $15.01 \pm 3.30$ & $11.86 \pm 3.76$ & $11.74 \pm 2.74$ & $13.23 \pm 3.73$ & $15.00 \pm 3.67$ \\
$\mathrm{OC}, \mathrm{ng} / \mathrm{ml}$ & $39.01 \pm 3.87^{*}$ & $37.80 \pm 3.87$ & $37.59 \pm 3.92$ & $36.94 \pm 3.45$ & $36.40 \pm 3.40$ & $36.01 \pm 3.22$ \\
\hline
\end{tabular}

$\mathrm{Ca}$ calcium, $\mathrm{Na}$ sodium, $\mathrm{Cl}$ chloride, $\mathrm{K}$ potassium, $\mathrm{P}$ phosphorus, $\mathrm{Fe}$ iron, $\mathrm{Cu}$ copper, $\mathrm{Zn}$ zinc, OC osteocalcin, significance: * vs 6 th month, $P<0.05$

\section{References}

Boskey AL, Gadaleta S, Gundberg C, Doty SB, Ducy P, Karsenty G (1998) Fourier transform infrared microspectroscopic analysis of bone osteocalcin deficient mice provides insight into the function of osteocalcin. Bone 23, 187-96

Catalano AL (1993) Morpho-functional evaluation of the horse. Noceto SBM, Italy [in Italian]

Inoue Y, Matsui A, Asai Y, Aoki F, Yoshimoto K, Matsui T, Yano H (2008) Response of biochemical markers of bone metabolism to exercise intensity in Thoroughbred horses. J Equine Sci 19, 83-9

Lepage OM, Carstanjen B, Uebelhart D (2001) Non-invasive assessment of equine bone: An update. Vet J $161,10-23$ 
Lepage OM, Descôteaux L, Marcoux M, Tremblay A (1991) Circadian rhythms of osteocalcin in equine serum. Correlation with alkaline phosphatase, calcium, phosphate and total protein levels. Can J Vet Res 55, 5-10

Risteli L, Risteli J (1993) Biochemical markers of bone metabolism. Ann Med 25, 385-93

Received 12 February 2010, accepted 10 March 2010.

Corresponding author:

GIUSEPPE PICCIONE

email: giuseppe.piccione@unime.it

Dipartimento di Scienze Sperimentali e Biotecnologie Applicate, Università di Messina, 98168 Messina, Italy 